\title{
Growth response of black velvet tamarind (Dialium guineense Willd) seedling to differ ent potting media
}

\author{
A. U. Osaigbovo* and C. N.C. N waoguala \\ Department of Crop Science, Faculty of Agriculture, University of Benin, Benin City, NIGERIA \\ *Corresponding author. E-mail: gbovosa@yahoo.com
}

Abstract: The response in growth and development of seedlings of Dialium guineense to different potting media was studied in the screen house. Five potting media: River sand (Rs), Top soil (Ts), Poultry manure (Pm), Rice husk $(\mathrm{Rh})$ and Oil palm refuse bunch (OPRB) were used. They were evaluated as sole treatments and in combination with river sand (Rs) in different ratios (1:1, 1:2, 2:5 and 5:2) respectively. All together, twenty - one (21) potting media types were evaluated. The experiment was laid out in a completely randomized design (CRD) in three replications. Data were collected on monthly basis for plant growth parameters, while shoot and root dry weight were measured at the end of the experiment. On the average the seedlings of $D$. guineense responded best on the Rs + Ts $1: 2$ growth medium in number of leaves $(16.67)$, stem girth $(0.31 \mathrm{~cm})$, number of nodes (11.67), shoot dry weight $(1.24$ g) and root dry weight $(0.50 \mathrm{~g})$. Rs + Ts $1: 2$ was followed by Rs + Pm 1:1 and Ts sole respectively with respect to the growth parameters evaluated and were not significantly $(p \leq 0.05)$ from one another, but were significantly $(p<0.05)$ different from other media and their combinations with river sand.

Keywords: Potting media, Dialium guineense, Seedling growth

\section{INTRODUCTION}

Dialium guineense also known as Black Velvet Tamarind (BVT) is an indigenous tropical forest fruit tree of the family Leguminosae. In Nigeria, BVT is called by various names depending on the locality or tribe. It is known as 'Tsamiyar kurmi' in Hausa's, 'Icheku' in Igbo, 'Awin' in the Yorubas and 'Amugen' in Edo language. BVT is an important non-timber multipurpose agroforestry crop with a high potential (Nwaoguala et al., 2007). The potentials of BVT as food supplement, in herbal medicine and as source of energy are well documented by Ogbe and Egharevba (1992), Aghartise and Egharevba (1994), Nwaoguala et al. (2007) and Nwaoguala and Osaigbovo (2009). According to Ogbe and Egharevba (1992), BVT is a lesser known tropical forest fruit with high consumption but given a less priority in terms of research, production, improvement, storage and hence not domesticated.

Efforts made so far to domesticate this crop had been concentrated on improving the germination of the seed through presowing treatments (Aghatise and Egharevba, 1994; Nwaoguala et al., 2007; Nwaoguala and Osaigbovo, 2009) which has been found to exhibit uneven and poor germination due to its thick gelatinous seed coat (Nwaoguala and Osaigbovo, 2009). The slow growth of BVT seedlings in the nursery also hampered the domestication of this crop. Hence, Nwaoguala and Osaigbovo (2009) suggested that more reliable ways of enhancing seedling production of BVT need to be developed.

The inclusion of organic materials such as farm yard manure, cow dung, compost etc as source of growth in potting media is essentials as it is the main source of organic matter for the supply of essential mineral nutrients needed by the plant (Khan et al., 2006). Organic materials ensure better seedling stand and vigorous growth which is needed to cope with the seasonal hazards encountered on the field (Khan et al., 2006). Thus, Egharevba et al. (2005) reported that a potting medium containing top soil and manure at a 2:1 ratio produced superior growth in African walnut (Plukenetia conophorus). Similarly, Osaigbovo et al. (2010) reported a superior growth of pepper fruit (D ennetia tripelata) seedlings raised in potting medium containing top soil and cow dung at a ratio of 2:1. Osaigbovo et al. (2009) recommended sole decomposed oil palm refuse bunch as a superior growth medium for African star apple (G a mbeya albida) seedlings. Poor growth of seedlings in potting media had been attributed to poor physical composition of the growth source which may have impeded aeration resulting in poor water and nutrients utilization (Osaigbovo et al., 2009). Hence, Dolor et al. (2009) recommended the amendment of growth sources with coarse minerals such as river sand to increase air filled pores and drainage. According to Hartman et al. (2007) an ideal potting media should provide porosity to allow good aeration. This study was aimed at determining the best potting medium 
and/or medium combinations on the seedling growth of $D$. guineense.

\section{MATERIALS AND METHODS}

Potting media: Five media sources (river sand, top soil, poultry manure, rice husk and oil palm refuse bunch) were used as source growth media. They were used as sole media and combined in different ratios $(1: 1,1: 2,2: 5$ and 5:2) with river sand to get twenty one (21) types of potting media as shown in Table 1 .

Potting media analysis: The growing media were analysed for their chemical characteristics. The $\mathrm{pH}$ was determined in water (1:1) using a glass electrode Beckman Zero-matics $\mathrm{pH}$ meter. The organic content was determined by the method of Walkley and Black (1947). Total nitrogen was determined by Microkjeldal method as described by Jackson (1962). Available phosphorus was extracted using Bray No 1 solution (Bray and Kurtz, 1945) and the phosphorus in the extract was assayed colorimetrically by the molybdenum blue method of Murphy and Riley (1962). The exchangeable bases were extracted using $1 \mathrm{~N}$ neutral ammonium acetate solution. Calcium and Magnesium of the extract were determined volumetrically by EDTA titration procedure of Black (1965). The potassium was read on the atomic absorption spectrophotometer. Bulk density was calculated by the formula derived by the America Society of Agronomy (Anonymous, 1965) as follows: Bulk density $(\mathrm{d})=$ Weight of oven dry core/ volume of the sample $\left(\mathrm{gcm}^{-3}\right)$.

Plant material: Mature fruits of BVT were depulped and treated with $98 \% \mathrm{H}_{2} \mathrm{SO}_{4}$ for $10 \mathrm{~min}$, rinsed in water six times and air dried. The seeds were then sown in seed trays filled with sterile soil. Germination occurred sporadically and the seedlings were transplanted 5 weeks later into a suitable plastic cup measuring $13.5 \times 14.5 \mathrm{~cm}$. The cups were perforated at the bottom. Each cup was filled with $2 \mathrm{~kg}$ of the different potting mixture. The trial was fitted into a completely randomized design (CRD) in 3 replications. Each replicate had 105 cups with 5 cups per treatment. The seedlings were watered ones every other day. Data on seedling growth were collected at every four (4) weeks interval. The parameters measured were plant height, number of leaves, number of nodes stem girth and canopy diameter. At the end of the trial (24 weeks after transplanting), the plants were harvested, separated into roots and shoots. They were oven dried at $70^{\circ} \mathrm{C}$ to a constant weight. Data collected were subjected to analysis of variance (ANOVA), using SAS Version 9 Software (2002), while the treatment means were separated using Least Significant Difference (LSD) at 5\% probability level.

\section{RESULTS AND DISCUSSION}

The results of the analysis of the potting media sources used are shown in Table 2 . All the media were slightly acidic with $\mathrm{pH}$ ranges of $5.11-6.20$ except for river sand which was slightly alkaline with a $\mathrm{pH}$ value of 8.0. The $\mathrm{pH}$ values for the media sources agreed with Khan et al. (2006) that the media $\mathrm{pH}$ value for container grown plant should be slightly acidic $(5.5-6.5)$. River sand had the highest bulk density of $1.7 \mathrm{gcm}^{-3}$, this was followed by top soil $\left(1.33 \mathrm{gcm}^{-3}\right)$, while the lowest bulk density was obtained in Rice husk $\left(0.70 \mathrm{gcm}^{-3}\right)$. The addition of river sand to the medium of growth can improve the physical status for better root development because of increased aeration of the media. Poultry manure recorded the highest value for nitrogen $(5.0 \%)$, phosphorus $(2.4 \%)$ and potassium ( $8.9 \%)$ and magnesium $(2.9 \%)$ while rice husk recorded the highest value for percentage organic carbon $(28.93 \%)$. The difference in the nutrient composition of the media sources may not be unconnected with the variation in the organic matter content in the different component of the growth media. River sand is inert with little or no nutrient elements hence, the low values recorded for percentage organic carbon, nitrogen, phosphorus, magnesium and calcium.

Responses to the media in the form of the morphological growth of BVT are presented in Table 3 and 4. BVT seedlings grown in potting medium of sole top soil recorded significantly $(\mathrm{p}<0.05)$ higher mean value of

Table 1. Potting media combination.

\begin{tabular}{ll}
\hline M edia combination & Ratio \\
\hline River sand (Rs) & Sole \\
Poultry manure (Pm) & Sole \\
Top soil (Ts) & Sole \\
Rice husk (Rh) & Sole \\
Oil palm refuse bunch (OPRB) & Sole \\
River sand + Top soil & $1: 1$ \\
River sand + Top soil & $1: 2$ \\
River sand + Top soil & $2: 5$ \\
River sand + Top soil & $5: 2$ \\
River sand + Poultry manure & $1: 1$ \\
River sand + Poultry manure & $1: 2$ \\
River sand + Poultry manure & $2: 5$ \\
River sand + Poultry manure & $5: 2$ \\
River sand + Rice husk & $1: 1$ \\
River sand + Rice husk & $1: 2$ \\
River sand + Rice husk & $2: 5$ \\
River sand + Rice husk & $5: 2$ \\
River sand + Oil palm refuse bunch & $1: 1$ \\
River sand + Oil palm refuse bunch & $1: 2$ \\
River sand + Oil palm refuse bunch & $2: 5$ \\
River sand + Oil palm refuse bunch & $5: 2$ \\
\hline &
\end{tabular}


Table 2. Some physical and chemical analysis of different potting sources.

\begin{tabular}{lcccccccc}
\hline Potting sources & $\mathrm{pH}$ & $\begin{array}{c}\text { Bulk density } \\
\left(\mathrm{gcm}^{-3}\right)\end{array}$ & $\begin{array}{c}\text { Org. C } \\
\%\end{array}$ & $\begin{array}{c}\mathrm{N} \\
\%\end{array}$ & $\begin{array}{c}\mathrm{P} \\
\%\end{array}$ & $\begin{array}{c}\mathrm{K} \\
\%\end{array}$ & $\begin{array}{c}\mathrm{Ca} \\
\%\end{array}$ & $\begin{array}{c}\mathrm{Mg} \\
\%\end{array}$ \\
\hline Top soil & 5.11 & 1.33 & 2.64 & 1.20 & 1.25 & 0.11 & 0.34 & 0.20 \\
Poultry manure & 6.11 & 1.10 & 4.21 & 5.00 & 2.48 & 8.90 & 2.00 & 2.90 \\
River sand & 8.0 & 1.70 & 0.06 & 0.05 & 0.03 & 0.01 & 0.05 & 0.10 \\
Rice husk & 6.5 & 0.70 & 28.93 & 0.06 & 1.34 & 0.05 & 2.30 & 0.81 \\
OPRB & 6.2 & 1.00 & 7.78 & 0.16 & 0.11 & 0.05 & 2.25 & 0.80 \\
\hline
\end{tabular}

Table 3. Effect of potting sources on growth parameters of BVT.

\begin{tabular}{lcccc}
\hline Potting media & Plant height $(\mathrm{cm})$ & Number of leaves & Stem girth $(\mathrm{cm})$ & Number of nodes \\
\hline River sand (Rs) sole & 8.33 & 4.00 & 0.17 & 5.35 \\
Poultry manure (Pm) sole & 10.67 & 11.00 & 0.24 & 6.00 \\
Top soil (Ts) sole & 18.27 & 13.67 & 0.28 & 10.33 \\
Rice husk (Rh) sole & 10.03 & 10.00 & 0.24 & 7.00 \\
Oil palm refuse bunch (OPRB) sole & 8.40 & 7.00 & 0.15 & 4.33 \\
Rs + Ts 1:1 & 15.67 & 12.67 & 0.28 & 9.33 \\
Rs + Ts 1:2 & 18.07 & 16.67 & 0.31 & 11.67 \\
Rs + Ts 2:5 & 15.53 & 16.33 & 0.27 & 9.66 \\
Rs + Ts 5:2 & 16.67 & 15.33 & 0.26 & 8.33 \\
Rs + Pm 1:1 & 16.33 & 15.60 & 0.28 & 11.33 \\
Rs + Pm 1:2 & 8.43 & 12.33 & 0.18 & 6.33 \\
Rs + Pm 2:5 & 8.57 & 7.00 & 0.49 & 2.67 \\
Rs + Pm 5:2 & 11.20 & 10.67 & 0.20 & 7.00 \\
Rs + Rh 1:1 & 10.17 & 9.33 & 0.17 & 6.33 \\
Rs + Rh 1:2 & 1033 & 10.67 & 0.20 & 5.33 \\
Rs + Rh 2:5 & 10.40 & 10.67 & 0.22 & 7.00 \\
Rs + Rh 5:2 & 11.10 & 8.33 & 0.19 & 5.33 \\
Rs + OPRB 1:1 & 10.47 & 6.67 & 0.17 & 3.67 \\
Rs + OPRB 1:2 & 10.27 & 9.00 & 0.17 & 6.00 \\
Rs + OPRB 2:5 & 10.17 & 9.33 & 0.18 & 6.33 \\
Rs + OPRB 5:2 & 9.90 & 9.00 & 0.17 & 6.00 \\
\hline LSD & 5.68 & 5.76 & 0.23 & 3.97 \\
\hline
\end{tabular}

$18.27 \mathrm{~cm}$ for plant height over other media types but was not significantly different from media with Rs + Ts $1: 1$ $(15.67 \mathrm{~cm}), \mathrm{RS}+\mathrm{Ts} 1: 2(18.07 \mathrm{~cm}), \mathrm{Rs}+\mathrm{Ts} 2: 5(15.53 \mathrm{~cm})$, Rs + Ts 5:2 $(16.67 \mathrm{~cm})$ and Rs + Pm 1:1 $(16.33 \mathrm{~cm})$. Number of leaves, stem girth and number of nodes were significantly $(\mathrm{p}<0.05)$ higher in potting mixture of Rs + Ts 1:2 over other combinations but was statistically nonsignificantly different from media with Ts sole, Rs + Ts 1:1, Rs + Ts 2:5, Rs + Ts 5:2, Pm sole, Rs + Pm 1:1 and Rs $+\operatorname{Pm} 1: 2$. The highest value for canopy diameter was recorded in potting mixture of $\mathrm{Rs}+\mathrm{Pm} 1: 1(13.7 \mathrm{~cm})$ while the lowest value was obtained in potting medium of OPRB sole $(8.00 \mathrm{~cm})$. Dry weight of shoot and root were significantly $(\mathrm{p}<0.05)$ higher in potting mixture of Rs +
Ts $1: 2(1.24 \mathrm{~g})$ and $(0.50 \mathrm{~g})$ respectively from most of the media types evaluated with exception in Ts sole, Rs + Ts 1:1, 2:5, 5:2 and Rs + Pm 1:1. Lawal et al. (2000) reported that sand and a mixture of top soil favours grape growth and that the best vine yard grows on moderately fertile, well drained sand or gravely loam soil which contains a good supply of organic matter. Buzzle.com (2001) recommended potting soil to sand at a ratio of $3: 1$ as ideal for growing indoor strawberries. The performance of $D$. guineense seedlings on media with Rs $+\operatorname{Pm}(1: 1)$ in some of the growth parameters agreed with Egharevba and Bamidele (1998) who reported a better seedling development in the growth of Chrysophyllum albidum grown in a medium containing top soil and poultry manure. 
Table 4. Effect of potting source on canopy diameter and dry weight of shoot and root.

\begin{tabular}{|c|c|c|c|}
\hline Potting media & Canopy diameter $(\mathrm{cm})$ & Shoot $(g)$ & Root $(g)$ \\
\hline River sand (Rs) sole & 9.70 & 0.39 & 0.39 \\
\hline Poultry manure $(\mathrm{Pm})$ sole & 8.60 & 0.39 & 0.17 \\
\hline Top soil (Ts) sole & 12.70 & 1.03 & 0.44 \\
\hline Rice husk (Rh) sole & 9.53 & 0.59 & 0.32 \\
\hline Oil palm refuse bunch (OPRB) sole & 8.00 & 0.26 & 0.08 \\
\hline Rs + Ts $1: 1$ & 13.30 & 0.90 & 0.33 \\
\hline Rs + Ts $1: 2$ & 12.97 & 1.24 & 0.50 \\
\hline Rs + Ts $2: 5$ & 12.50 & 0.96 & 0.44 \\
\hline Rs + Ts 5:2 & 13.03 & 0.73 & 0.37 \\
\hline $\mathrm{Rs}+\mathrm{Pm} 1: 1$ & 13.70 & 0.97 & 0.37 \\
\hline $\mathrm{Rs}+\mathrm{Pm} 1: 2$ & 9.67 & 0.37 & 0.13 \\
\hline $\mathrm{Rs}+\mathrm{Pm} 2: 5$ & 8.00 & 0.20 & 0.07 \\
\hline $\mathrm{Rs}+\mathrm{Pm}$ 5:2 & 9.13 & 0.31 & 0.16 \\
\hline $\mathrm{Rs}+\mathrm{Rh} 1: 1$ & 8.37 & 0.37 & 0.20 \\
\hline $\mathrm{Rs}+\mathrm{Rh} 1: 2$ & 8.90 & 0.56 & 0.27 \\
\hline $\mathrm{Rs}+\mathrm{Rh} 2: 5$ & 8.87 & 0.55 & 0.27 \\
\hline $\mathrm{Rs}+\mathrm{Rh} 5: 2$ & 9.80 & 0.42 & 0.28 \\
\hline Rs + OPRB 1:1 & 9.47 & 0.25 & 0.10 \\
\hline Rs + OPRB 1:2 & 10.77 & 0.25 & 0.09 \\
\hline Rs + OPRB 2:5 & 10.07 & 0.31 & 0.12 \\
\hline Rs + OPRB 5:2 & 9.50 & 0.36 & 0.16 \\
\hline LSD & 4.11 & 0.52 & 0.22 \\
\hline
\end{tabular}

According to Reddy and Reddi (1995) manure from monogastric such as poultry are effective fertilizers, they are important sources of plant nutrients. The more enhanced growth observed in the media of Ts and Pm amended with Rs (Rs + Ts 1:2 and Rs + Pm 1:1) may be due to the improvement of the physical status of the mixture resulting from the amendment with river sand and the proportion of the mixture. According to Osaigbovo et al. (2009), river sand is coarse with loose particle size that can improve the physical composition when combined with other potting media source for better root development, moisture and nutrient utilization because of increased aeration. Dewayne et al. (2003) reported that aeration and water holding capacity of a potting medium is the most important physical factor. The poor seedling growth observed in sole OPBR (Tables 3 and 4) was not in line with the report of Aminah et al. (2004) on Shorea loprosula and Osaigbovo et al. (2009) on Gambeya albida seedlings. Both reported superior growth of seedlings raised in sole OPRB. The poor performance could be due to the degree of composting. This study has shown that top soil and poultry manure amended with river sand at a ratio $1: 2$ and 1:1 respectively are most suitable media for the growth of $D$. guineense. These could be used as standard potting media for raising $D$. guineense in the nursery. These materials are abundant and could be cheaply sourced.

\section{ACKNOWLEDGEMENTS}

The authors wish to acknowledge Mr. Aikhomu Osamudiamen Stevenson for his assistance with data collection.

\section{REFERENCES}

Aghatise, O. V. and Egharevba, R. K. (1994). Response of Dialium guineense to pregermination treatments. Nitrogen Fixing Tree Report,12: 54 - 55

Aminah, H. Ab Rasiq, A.G., Mohd, Z.A., Abdul Khalim, E. and Yusus, Y. (2004). Effect of potting media and size of root trainers in the growth Shorea leprosula.http://www. cabastractsplus.org/abstracts/abstract:Ac=20043132727.

Anonymous (1965). Methods of Soil Analysis, part 1, America Society of Agronomy. Madison, Wisconnin, 82 - 93pp.

Black, C.A. (1965). Method of soil analysis: Part II American Society of Agriculture M onographs, (9): 1374-1375.

Bray, R.H. and Kurtz, L.T. (1945). Determination of total organic and available forms of phosphorus in soils. Soil Science, 59: 39- 45 .

Buzzle.com(2011). Growing strawberries indoors. www.buzzle.com/article/growing-strawberries-indoors

Dewayne, L.I., Rich, W.H. and Thomas, H.Y. (2003). Growth media for container grown ornamental plants. The environmental horticulture department, Florida co-operative extension service, Institute of Food and Agriculture Science, University of Florida Bulletin, 241.

Dolor, D. E., Ikie, F. O and Nnaji, G. U. (2009). Effect of propagation media on the rooting of leafy stem cuttings of 
I rvingia wombolu (Vermoesen). J ournal of Agriculture and Biological Sciences, 5 (6) : 1146- 1152.

Egharevba, R.K.A and Bamidele, J. F. (1998). The growth response of Chrysophyllum albidum seedlings to different potting mixture. Nigerian J ournal of $\mathrm{H}$ orticultural Science, 3: $71-79$.

Egharevba, R.K.A., Ikhatua, M.I. and Kalu, C. (2005). The Influence of Seed Treatments and Growing Media on Seedling Growth and Development of African Walnut. Plukenetia conophorum. African J ournal of Biotechnology, 4 (8): 808 - 811.

Hartmann, H. T., Kester, D. E., Davies, F. I and Genve, R. I. (2007). Hartmann and Kester's Plant Propagation, Principles and Practices. $7^{\text {th }}$ edition. Prentice-Hall of India Ltd. 880pp.

Jackson, M. L. (1962). Soil chemical analysis. Constable and co ltd, London, UK. pp. 123.

Khan, M.M., Khan, A.M., Abbas, M., Muhammed, J., Jaskani, M., Ali, A. and Haider, A. (2006). Evaluation of potting media for the production of rough lemon nursery stock. Pak. J. Bot., 38(3): 623-629.

Lawal, A.B., Ahmed, M.R. Amans, E.D. and Ibrahim, R. (2000). Effect of rooting media and varieties on root and shoot growth of fresh grape vine. Nigerian J ournal of H orticulture Science, 4: 46-56.

Nwaoguala, C.N.C., Osaigbovo, A.U. and Orhue, E.R. (2007). Seed treatment for development of seedlings of Black Velvet Tamarind (D ialium guineense). African J ournal of $\mathrm{G}$ eneral Agriculture, 3: 49-51.
Nwaoguala, C.N.C. and Osaigbovo, A.U. (2009). Enhancing seedling production of Black Velvet Tamarind (Dialium guineense ). J ournal of A pplied and Natural Science,1(1): 36-40.

Ogbe, O.F. and Egharevba, R.K.A (1992). Indigenous food plant. Field survey of indigenous and useful plants, their preparation for food and home garden, Edo/Delta States of Nigeria. University programme on National Research in Africa, 1: 132-134.

Osaigbovo, A.U., Nwaoguala, C.N.C. and Falodun, J. E. (2009). Influence of different potting media on the seedling growth of G ambeya albida (G.Don). J ournal of Sustainable Tropical Agriculture Research, 31: 77-81.

Osaigbovo, A.U., Nwaoguala, C.N.C and Fadodun, J.E. (2010). Evaluation of potting media for the production of pepper fruit (D ennetia tripetala) seedlings. African J ournal of General Agriculture, 6 (2): 47-51.

Reddy, T.V. and Reddi, G. H. (1995). Principles of Agronomy. $2^{\text {nd }}$ Edition, Kalyani Publisher, New Delhi. 223pp.

Murphy, J. and Riley, J. P. (1962). Modified simple solution method for the determination of phosphorus in natural water. Analytical Chemistry Acta., (27) : 31-37.

SAS (2002). (Statistical Analysis System). SAS Version of software, SAS, Institute Inc., Lang. N.J ., 27513, USA.

Walkley, J. and Black, C. A. (1947). A critical examination of a rapid method for determining organic carbon in soils: Effects of variation in digestion condition and of organic carbon constituents. Soil Science, 63: 251-263. 